\title{
Tanggung Jawab Sosial Perusahaan Bukan Sumber Daya Alam dalam Perspektif ISO 26000
}

\author{
Yuman Nur Rozak \\ Magister Hukum Fakultas Hukum Universitas Islam Indonesia Yogyakarta Indonesia \\ Jln. Cik Di Tiro No. 1 Yogyakarta Indonesia \\ yumannr@gmail.com
}

\begin{abstract}
This study analyzes first, how is the regulation of CSR in Indonesia in accordance with ISO 26000? Second, how should the regulations and CSR formulations address the legal vacuum of non-natural resource companies in Indonesia? This research uses normative juridical method. The results of this study conclude that first, that the regulation of CSR in Indonesia is not in accordance with the regulations contained in ISO 26000. CSR regulations in Indonesia are still scattered in several laws and regulations. Non-natural resource companies are not required to carry out CSR even though their business activities have a major impact on the social and environmental environment. Second, there is a need for special regulations that regulate the implementation and mechanism for implementing CSR in Indonesia in an integrated and codified manner. The regulation of CSR in Indonesia needs to be reformulated by adopting the principles of CSR implementation contained in ISO 26000, in the form of a law which contains two main provisions, namely the implementation of CSR for natural resources companies and the implementation of CSR for non-natural resources companies.
\end{abstract}

Key Words: CSR; company; ISO 26000; non-natural resources; regulation

\begin{abstract}
Abstrak
Penelitian ini menganalisis, pertama, apakah pengaturan CSR di Indonesia sudah sesuai dengan ISO 26000? Kedua, bagaimanakah seharusnya regulasi dan formulasi CSR untuk mengatasi kekosongan hukum terhadap perusahaan bukan SDA di Indonesia? Penelitian menggunakan metode yuridis normatif. Hasil kajian ini menyimpulkan, pertama, pengaturan CSR di Indonesia tidak sesuai dengan pengaturan yang terdapat dalam ISO 26000. Regulasi CSR di Indonesia masih tersebar di beberapa peraturan perundang-undangan. Perusahaan bukan SDA tidak diwajibkan untuk melaksanakan CSR meskipun kegiatan usahanya sangat berdampak pada lingkungan sosial dan lingkungan hidup. Kedua, perlu adanya regulasi secara khusus yang mengatur implementasi dan mekanisme pelaksanaan CSR di Indonesia secara terpadu dan terkodifikasi. Pengaturan CSR di Indonesia perlu diformulasikan ulang dengan mengadopsi prinsip-prinsip pelaksanaan CSR yang terdapat dalam ISO 26000, dalam bentuk Undang-Undang yang di dalamnya memuat dua ketentuan utama yakni pelaksanaan CSR bagi perusahaan SDA dan pelaksanaan CSR bagi perusahaan bukan SDA.
\end{abstract}

Kata-kata Kunci: CSR; perusahaan; bukan SDA; ISO 26000; peraturan 


\section{Pendahuluan}

Penerapan tanggung jawab sosial perusahaan atau Corporate Social Responsibility (CSR) sangat penting dilaksanakan di Indonesia. Hal ini didasarkan pada fakta di lapangan bahwa dunia industri sudah berkembang pesat selama 10 tahun terakhir, ${ }_{1}^{1}$ termasuk banyaknya perusahaan multinasional yang ikut ambil bagian dalam perkembangan (di Indonesia) tersebut. ${ }^{2}$ Sektor industri di Indonesia telah menyumbang kontribusi terbesar bagi perekonomian nasional, yakni secapai lebih dari 20 persen. ${ }^{3}$ Bahkan, dalam kategori manufacturing value added, ${ }^{4}$ Indonesia telah masuk dalam 10 besar peringkat di dunia, yang sejajar dengan Brasil dan Inggris. Sektor industri juga telah memberikan manfaat dalam hal penyerapan tenaga kerja. Pada 2018, penyerapan tenaga kerja industri manufaktur yakni sebanyak 18,25 juta orang. Sehingga, dalam persentase maka industri manufaktur telah berkontribusi sebanyak 14,72 persen dari total tenaga kerja nasional. ${ }^{5}$

Sektor industri juga banyak menimbulkan permasalahan di tengah masyarakat, khususnya dari sisi lingkungan hidup yang banyak rusak akibat kegiatan maupun limbah industri. 6 Oleh karenanya, kemudian timbul inisiatif untuk mengurangi resiko kerusakan lingkungan melalui mekanisme pelaksanaan Corporate Social responsibility (CSR).

Undang-Undang Nomor 40 Tahun 2007 tentang Perseoran Terbatas (UU PT), sebagai salah satu aturan di Indonesia yang mengatur mengenai CSR yakni khususnya dalam Pasal 74, ternyata tidak cukup kuat untuk menjadi landasan terkait pelaksanaan CSR bagi suatu perusahaan yang beroperasi di Indonesia. Mukti Fajar mengatakan jika Pasal 74 UU PT tersebut melahirkan beberapa persoalan, yaitu: (a) diskriminasi bagi perusahaan Perseroan Terbatas dan (b) diskriminasi hanya bagi perusahaan yang bergerak di bidang sumber daya alam dan atau terkait saja. Selain yang tersebut dianggap tidak dibebani kewajiban CSR. ${ }^{7}$

${ }^{1}$ https://www.liputan6.com/bisnis/read/3980293/menperin-industri-di-ri-berkembang-pesat-dalam-10tahun-terakhir, "Menperin: Industri di RI Berkembang Pesat dalam 10 Tahun Terakhir (31 Mei 2019)", Akses 15 April 2020

2 https://kompas.id/baca/ekonomi/2019/01/25/tiga-perusahaan-multinasional-tambah-investasi-diindonesia/. "Tiga perusahaan Multinasional Tambah Investasi di Indoensia”. Akses 15 April 2020

3 Kementerian Perindustrian Republik Indonesia, "Indonesia Masuk Kategori Negara Industri", dalam https://kemenperin.go.id/artikel/18473/Indonesia-Masuk-Kategori-Negara-Industri. Akses 15 april 2020

4 Manufacturing value added (MVA) sebagaimanana didefinisikan oleh UNIDO (United Nations Industrial Development Organization) adalah "Manufacturing value added (MVA) of an economy is the total estimate of net-output of all resident manufacturing activity units obtained by adding up outputs and subtracting intermediate inputs." Dalam https://stat.unido.org/content/learning-center/what-is-manufacturing-value-added $\% 253 \mathrm{f}$

5https://kemenperin.go.id/artikel/20288/Penyerapan-Tenaga-Kerja-Industri-Manufaktur-TerusMeningkat. "Penyerapan Tenaga Kerja Industri Manufaktur Terus Meningkat”. Akses 15 april 2020

'https://www.mongabay.co.id/2016/06/06/ beginilah-visualisasi-pencemaran-industri-di-hari-lingkunganhidup/. "Beginilah Visualisasi Pencemara Industri di Hari Lingkungan Hidup"dalam Akses 15 April 2020

${ }^{7}$ Mukti Fajar, Tanggungjawab Sosial Perusahaan di Indonesia, Pustaka Pelajar, Yogyakarta, 2013, hlm. 286 
Perusahaan yang tidak terkait langsung dalam pengelolaan dan pengolahan sumber daya alam (perusahaan non SDA) juga menimbulkan dampak lingkungan maupun dampak sosial di sekitar operasional perusahaan. Dampak lingkungan yang timbul akibat usaha perusahaan non SDA mungkin tidak separah dari dampak perusahaan yang berkaitan dengan SDA. Namun, apabila berbicara mengenai dampak sosial, maka dampak yang timbul setara atau malah bisa lebih tinggi daripada perusahaan pengolahan SDA. Hal ini dapat dilihat bahwa perusahaan non SDA justru lebih banyak yang kegiatan operasionalnya berdekatan dengan pemukiman masyarakat lokal. ${ }^{8}$ Inilah salah satu alasan kuat bagi penulis untuk mendorong adanya pewajiban CSR bagi semua bentuk badan usaha.

Penerapan CSR bagi perusahaan non SDA di Indonesia juga dinilai tidak lagi sejalan dengan penerapan CSR di taraf internasional. Di dunia internasional telah lahir panduan dan standarisasi penerapan CSR yang diberi nama ISO 26000: Guidance Standard on Social Responsibility. ${ }^{9}$ ISO 26000 ini kemudian memberikan 7 isu pokok yakni: Pengembangan masyarakat; Konsumen; Praktik kegiatan institusi yang sehat; Lingkungan; Ketenagakerjaan; Hak Asasi Manusia; dan Organization Governance (Organisasi Kepemerintahan). ISO 26000 telah mewajibkan bagi seluruh bentuk organisasi untuk melaksanakan CSR.

\section{Rumusan Masalah}

Penelitian ini fokus mengkaji dua rumusan masalah, pertama, apakah pengaturan CSR di Indonesia sudah sesuai dengan ISO 26000? Kedua, bagaimanakah seharusnya regulasi dan formulasi CSR untuk mengatasi kekosongan hukum terhadap perusahaan non sumber daya alam di Indonesia?

\section{Tujuan Penelitian}

Penelitian ini bertujuan, pertama untuk menganalisis perbandingan pengaturan CSR di Indonesia dengan ISO 26000; kedua, untuk menganalisis regulasi dan melakukan formulasi pengaturan CSR yang baru terhadap perusahaan non sumber daya alam di Indonesia.

${ }^{8}$ Dinara Falif, Kehadiran Pabrik di Tengah Permukiman, 22 Maret 2020, diakses pada 1 Juni 2020, pada https://www.kompasiana.com/dinarafalif/5e76d6de097f367e6e39f572/kehadiran-pabrik-di-tengah-permukimanwarga

9 Mas Achmad Daniri, "Standarisasi Tanggungjawab Sosial Perusahaan", dalam http://kadinindonesia.or.id/enm/images/dokumen/KADIN-167-3770-15042009.pdf, Akses 10 Oktober 2018 


\section{Metode Penelitian}

Metode penelitian merupakan bagian dari ilmu pengetahuan yang mempelajari bagaimana prosedur kerja mencari kebenaran. ${ }^{10}$ Jenis penelitian yang digunakan dalam penelitian ini yakni adalah penelitian hukum yuridisnormatif. ${ }^{11}$ Sumber data dalam penelitian ini yakni Penelitian Kepustakaan (Library Research) dipilih oleh penulis untuk memperoleh data sekunder yang terdiri dari: Bahan hukum primer meliputi: peraturan perundang-undangan yang terkait, bahan hukum sekunder berupa buku, jurnal, dan hasil penelitian, serta bahan hukum tersier berupa kamus hukum. Metode analisis bahan hukum yang dipergunakan dalam penelitian ini adalah deskriptif kualitatif yaitu pengelompokan dan penyelesaian data-data yang diperoleh dari suatu gambaran sistematis yang didasarkan pada teori dan pengertian hukum yang terdapat dalam ilmu hukum untuk mendapatkan kesimpulan yang ilmiah. ${ }^{12}$

\section{Hasil Penelitian dan Pembahasan}

\section{Pengaturan Corporate Social Responsibility di Indoensia Belum Memenuhi Standar ISO 26000}

Pasal 74 UU PT menyebutkan bahwa Perseroan yang menjalankan kegiatan usahanya di bidang dan/atau berkaitan dengan sumber daya alam wajib melaksanakan tanggung jawab sosial dan lingkungan. Jika tidak melaksanakannya maka diperlakukan sanksi sesuai dengan ketentuan peraturan perundangundangan. ${ }^{13}$ Penjelasan Pasal 74 ayat (1) tersebut menjelaskan bahwa kewajiban CSR bagi perusahaan yang menjalankan kegiatan usahanya di bidang dan/atau berkaitan dengan SDA ini tidak hanya melihat pada fokus bisnis perusahaan tersebut. Walaupun perusahaan tersebut tidak secara langsung melaksanakan eksploitasi SDA, tetapi selama kegiatan usahanya berdampak pada fungsi kemampuan SDA, maka perusahaan tersebut wajib melaksanakan tanggung jawab sosialnya. ${ }^{14}$

\section{Regulasi Corporate Social Responsilibilty di Indonesia}

CSR di Indonesia di atur dalam beberapa peraturan perundang-undangan mulai dari Undang-Undang hingga Peraturan Pemerintah. Setidaknya terdapat 7

\footnotetext{
12 Burhan Bungin, Metodologi Penelitian Kualitatif: Komunikasi, Ekonomi, dan Kebijakan Publik serta Ilmu-ilmu Sosial Lainnya, Prenada Media Group, Jakarta, 2010, hlm. 150

13 Sukarmi, "Tanggung jawab Sosial Perusahaan (Corporate Social Responsibility) dan Iklim Penanaman Modal", dalam http//www.madani-ri.com, Akses 18 Januari 2019

14 Penjelasan Pasal 74 ayat (3). Yang dimaksud dengan "dikenai sanksi sesuai dengan ketentuan peraturan perundang-undangan" adalah dikenai segala bentuk sanksi yang diatur dalam peraturan perundang-undangan yang terkait
} hlm. 45

${ }^{10}$ Noeng Muhadjir, Metode Penelitian Kualitatif, Cetakan I, Penerbit Rake Saarasin, Yogyakarta, 2000, hlm. 5

${ }^{11}$ Johnny Ibrahim, Teori dan Metodologi Penelitian Hukum Normatif, Bayu Media Publishing, Surabaya, 2005, 
Undang-Undang, 2 Peraturan Pemerintah, dan 1 Peraturan Menteri yang mengatur mengenai CSR. Adapun beberapa peraturan perundang-undangan yang mengatur mengenai CSR di Indonesia yakni sebagai berikut.

a. Undang-Undang Nomor 40 Tahun 2007 tentang Perseroan Terbatas Undang-Undang Nomor 40 Tahun 2007 tentang Perseroan Terbatas mengatur mengenai CSR hanya terdapat dalam Bab V yang mengatur tentang Tanggung Jawab Sosial dan Lingkungan, tepatnya pada Pasal 74. Terdapat 4 ayat pada Pasal 74 UU PT, yang pada intinya mengatur mengenai kewajiban perseroan untuk melaksanakan tanggung jawab sosial dan lingkungan.

Pasal 74 merupakan satu-satunya pasal yang mengatur mengenai CSR dalam UU PT. Berdasarkan pasal tersebut, maka CSR hanya diwajibkan kepada perseroan $^{15}$ yang menjalankan kegiatan usahanya di bidang dan/atau berkaitan dengan SDA. Dalam penjelasan Pasal 74 ayat (1) UU PT, yang dimaksud dengan perseroan yang menjalankan kegiatan usahanya di bidang SDA adalah perseroan yang kegiatan usahanya mengelola dan memanfaatkan SDA. Sedangkan yang dimaksud dengan perseroan yang menjalankan kegiatan usahanya berkaitan dengan SDA adalah perseroan yang tidak mengelola dan tidak memanfaatkan sumber daya alam, tetapi kegiatan usahanya berdampak pada fungsi kemampuan SDA.

Perseroan tersebut harus memasukkan kebutuhan dan pembiayaan CSR dalam anggaran perusahaan yang pelaksanaannya dilakukan dengan memperhatikan kepatutan dan kewajaran. Frasa "kepatutan dan kewajaran" sebagaimana yang disebut dalam Pasal 74 ayat (2) tersebut tidak diuraikan lebih lanjut. Dalam penjelasan pasalnya, hanya dituliskan "cukup jelas".

Pasal 74 ayat (3) UU PT mengatur mengenai penerapan sanksi bagi perusahaan yang tidak melaksanakan kewajiban CSRnya. Dalam bagian penjelasan, yang dimakud dengan "dikenai sanksi sesuai dengan ketentuan peraturan perundang-undangan" adalah dikenai segala bentuk sanksi yang diatur dalam peraturan perundang-undangan terkait.

b. Undang-Undang Nomor 25 Tahun 2007 tentang Penanaman Modal

Undang-Undang Nomor 25 Tahun 2007 tentang Penanaman Modal mengatur kewajiban CSR kepada penanam modal dalam sebuah perseoran atau perusahaan. Pengaturan CSR dalam UU PM terdapat pada Pasal 15 huruf b, Pasal 16, dan Pasal 34. Dalam Pasal 15 huruf b, penanam modal diwajibkan untuk melaksanakan tanggung jawab sosial perusahaan. ${ }^{16}$ Sedangkan, dalam

15 Perseroan, berdasarkan Pasal 1 angka 1 UU PT, adalah badan hukum yang merupakan persekutuan modal, didirikan berdasarkan pernjanjian, melakukan kegiatan usaha dengan modal dasar yang seluruhnya terbagi dalam saham dan memenuhi persyaratan yang ditetapkan dalam UU PT serta peraturan pelaksananya.

${ }^{16}$ Pasal 15 huruf b UU PM: "Setiap penanam modal berkewajiban: b. melaksanakan tanggung jawab sosial perusahaan." 
Pasal 16 UU PM juga mengatur bahwa setiap penanam modal bertanggung jawab untuk menjaga kelestarian lingkungan hidup yang juga merupakan bagian dari pewajiban pelaksanaan CSR bagi perusahaan.

Dalam hal perusahaan atau penanam modal tidak melaksanakan CSR, maka sanksi akan diberikan sebagaimana diatur dalam Pasal 34 UU PM. Penanam modal dapat dikenai sanksi administratif. Selain sanksi administratif, penanam modal yang tidak melaksanakan kewajibannya untuk melaksanakan CSR juga dapat dikenai sanksi lain sesuai dengan ketentuan peraturan perundangundangan sebagai diatur dalam Pasal 34 ayat (3) UU PM.

c. Undang-Undang Nomor 21 Tahun 2014 tentang Panas Bumi Undang-Undang Nomor 21 Tahun 2014 tentang Panas Bumi mengatur CSR dalam Pasal 65 ayat (2) huruf b. Pasal tersebut mewajibkan pada seluruh perusahaan yang melaksanakan usaha panas bumi untuk melaksanakan kewajibannya untuk memenuhi tanggung jawab sosial perusahaan dan/atau pengembangan masyarakat di sekitar kegiatan usaha panas bumi.

d. Undang-Undang Nomor 4 Tahun 2009 tentang Pertambangan Mineral dan Batubara

Undang-Undang Nomor 4 Tahun 2009 tentang Pertambangan Mineral dan Batubara ini tidak menyebutkan pengaturan mengenai CSR secara tersurat. Namun, Pasal 108 ayat (1) UU Minerba menggunakan istilah "pengembangan dan pemberdayaan masyarakat" yang ada intinya melaksanakan substansi dari CSR itu sendiri.

e. Undang-Undang Nomor 22 Tahun 2001 tentang Minyak dan Gas Bumi Undang-Undang Nomor 22 Tahun 2001 tentang Minyak dan Gas Bumi secara tersurat tidak mengatur mengenai CSR. Namun, dalam Pasal 11 ayat (3) huruf p secara tersirat menyinggung mengenai pekasanaan CSR.

"Kontrak Kerja Sama sebagaimana dimaksud dalam ayat (1) wajib memuat palin sedikit ketentuan-ketentuan pokok yaitu: pengembangan masyarakat sekitarnya dan jaminan hak-hak masyarakat adat."

Frasa "pengembangan masyarakat sekitarnya dan jaminan hak-hak masyarakat adat" ini sangat berkaitan erat dengan substansi dari CSR itu sendiri. Sebagaimana yang telah dijelaskan sebelumnya, salah satu tujuan CSR adalah untuk turut serta mengembangkan masyarakat dan lingkungan di sekitar wilayah usaha.

f. Undang-Undang Nomor 13 Tahun 2011 tentang Penanganan Fakir Miskin Undang-Undang Nomor 13 Tahun 2011 tentang Penanganan Fakir Miskin ini setidaknya terdapat 2 pasal yang menyinggung mengenai CSR yakni Pasal 36 
ayat (1) huruf c dan Pasal 41. Pasal 36 ayat (1) huruf c UU Fakir Miskin ${ }^{17}$ menyatakan bahwa salah satu sumber pendanaan dalam penanganan fakir miskin bersumber dari dana yang disisihkan dari perusahaan perseroan. Dalam ayat (2)-nya, dijelaskan bahwa dana yang disisihkan dari perusahaan perseroan tersebut digunakan sebesar-besarnya untuk penanganan fakir miskin.

g. Undang-Undang Nomor 32 Tahun 2009 tentang Perlindungan dan Pengelolaan Lingkungan Hidup Undang-Undang Nomor 32 Tahun 2009 tentang Perlindungan dan Pengelolaan Lingkungan Hidup (UU PPLH) mengatur CSR di dalam Pasal 68.

h. Peraturan Pemerintah Nomor 47 Tahun 2012 tentang Tanggung Jawab Sosial dan Lingkungan Perseroan Terbatas

Selain ke tujuh undang-undang sebagaimana telah diuraikan di atas, terdapat satu Peraturan Pemerintah yang diterbitkan berdasarkan amat Pasal 74 ayat (4) UU PT yakni Peraturan Pemerintah Nomor 47 Tahun 2012 tentang Tanggung Jawab Sosial dan Lingkungan Perseroan Terbatas (PP No. 47/2012). PP ini masih belum mengatur secara rinci mekanisme dan pelaksanaan CSR secara patut belum terdapat penjelasan yang tegas dan pasti mengenai parameter dan ukuran yang dapat digunakan sebagai penilaian pelaksanaan CSR.

i. Peraturan Pemerintah Nomor 23 Tahun 2010 tentang Pelaksaaan Kegiatan Usaha Pertambangan Mineral dan Batubara

Dalam Peraturan Pemerintah Nomor 23 Tahun 2010 tentang Pelaksanaan Kegiatan Usaha Pertambangan Mineral dan Batubara (PP No. 23/2010) ini, menjelaskan lebih lanjut mengenai frasa "pengembangan dan pemberdayaan masyarakat" yang sebelumnya telah disinggung dalam UU Minerba.

PP No. 23/2010 ini merupakan aturan pelaksana dari UU Minerba. Dalam Bab XII PP No 23/2010 ini, terdapat 4 (empat) pasal yang mengatur mengenai pengembangan dan pemberdayaan masyarakat.

j. Peraturan Menteri Badan Usaha Milik Negara No. PER-08/MBU/2013 Tahun 2013 tentang Perubahan Keempat Atas Peraturan Menteri Negara Badan Usaha Milik Negara No. Per-05/MBU/2007 Tahun 2007 tentang Program Kemitraan Badan Usaha Milik Negara Dengan Usaha Kecil Dan Program Bina Lingkungan Permen BUMN 2013 ini telah mengatur mengenai kewajiban Perusahaan Perseroan, Perusahaan Umum, dan Perusahaan Perseroan Terbuka. Berdasarkan pada Pasal 2 Permen BUMN 2013, Persero dan Perum diwajibkan

17 Pasal 36 ayat (1) UU Fakir Miskin: “(1) Sumber pendanaan dalam penanganan fakir miskin meliputi: a. Anggaran Pendapatan dan Belanja Negara; $b$. anggaran pendapat dan belanja daerab; c. dana yang disisibkan dari perusahaan perseroan; d. dana hibah baik dalam maupun luar negeri; dan e. sumber dana lain yang sab dan tidak mengikat." 
untuk melaksanakan program kemitraan BUMN dengan usaha kecil. Sedangkan, Perseroan Terbuka diwajibkan untuk melaksanakan program kemitraan dengan usaha kecil dan program bina lingkungan dengan berpedoman pada Permen BUMN 2013 yang ditetapkan berdasarkan keputusan RUPS.

\section{Regulasi Corporate Social Responsilibilty Berdasarkan ISO 26000}

Para ahli yang merumuskan ISO 26000 Guidance Standard on Social Responsibility secara konsisten mengembangkan tanggung jawab sosial maka masalah Social Responsibility akan mencakup 7 isu pokok yaitu:

a. Pengembangan Masyarakat

Masyarakat dalam arti sempit biasanya disebut komunitas atau community. Bila masyarakat didefenisikan seperti pengertian pertama, yakni sebagai komunitas, maka pengembangan masyarakat biasanya difokuskan pada pengembangan kegiatan-kegiatan pembangunan lokal (locality development) pada pemukiman atau wilayah yang relatif kecil, misalnya dalam bentuk dukungan pengembangan ekonomi. Bila masyarakat didefenisikan secara lebih luas lagi, maka pengembangan masyarakat seringkali melibatkan kegiatankegiatan advokasi atau aksi sosial yang menuntut adanya perubahan kebijakan publik yang umumnya menyentuh konteks politik. ${ }^{18}$

Pengembangan masyarakat merupakan wawasan dasar bersistem tentang asumsi perubahan sosial terancang yang tepat dalam kurung waktu tertentu. Perbaikan mutu sumber daya manusia akan menumbuhkan inisiatif dan kewirausahaan.19

b. Konsumen

Program CSR ini melibatkan aspek kualitatif suatu produk atau jasa, antara lain kegunaan, durability, pelayanan, kepuasan pelanggan, kejujuran dalam iklan, kejelasan atau kelengkapan isi pada kemasan, dan lainnya. Perusahaan seharusnya memberikan kualitas produk dan jasa yang baik kepada masyarakat. Perusahaan tidak semata-mata mencari laba tetapi ada tanggung jawab etis kepada masyarakat atas produk dan jasa yang diberikan.

c. Praktik Kegiatan Institusi yang Sehat

Etika bisnis merupakan seperangkat kesepakatan umum, yaitu mengatur antara relasi antar pelaku bisnis dan antara pelaku bisnis dengan masyarakat, agar hubungan tersebut terjalin dengan baik dan fair. Makna tersirati bahwa

${ }^{18}$ Edi Suharto, "Pengembangan Masyarakat Dalam Praktik Pekerja Sosial", Makalah disampaikan pada Pelatihan Pengorganisasian dan Pengembangan Masyarakat, Jurusan Ilmu Kesejahteraan Sosial FISIP Universitas Jember, Jember, 28 September 2006, hlm 12

19 Asep Mulyadi, "Pengembangan Sumber Daya Manusia dalam Mendukung Program Konservasi Lingkungan Laguna Segaraanakan”, dalam http://ejournal.upi.edu/index.php/gea/article/viewFile/1682/1134, Akses 2 Maret 2019 
perusahaan tidak diharapkan pada tanggung jawab yang hanya berpijak pada single bottom line, yaitu nilai perusahaan yang direfleksikan dalam kondisi keuangan saja. Tanggung jawab perusahaan harus berpijak selain aspek ekonomi tetapi juga sosial dan lingkungan.

d. Lingkungan

Perusahaan dalam menerapkan CSR dengan lingkup yang berkaitan dengan lingkungan hidup. Tema ini meliputi aspek lingkungan dari proses produksi, yang meliputi pengendalian polusi dalam menjalankan operasi bisnis, pencegahan dan perbaikan kerusakan lingkungan akibat pemrosesan sumber daya alam dan konversi sumber daya alam.

e. Ketenagakerjaan

Tema yang dapat diambil dalam program CSR ini merupakan semua aktivitas perusahaan yang ditujukan pada orang-orang dalam perusahaan sendiri. Aktivitas tersebut meliputi rekruitmen, program pelatihan, gaji dan tunjangan, mutasi dan promosi, dan lainnya. Karyawan merupakan sumber daya penting dalam pencapaian tujuan perusahaan, oleh karena itu perusahaan berkewajiban untuk memperhatikan dan meningkatkan kualitas maupun kesejahteraan karyawan. ${ }^{20}$

f. Hak Asasi Manusia

Operasi perusahaan telah mengancam potensi terjadinya pelanggaran HAM. Maka peran CSR di dalam dapat memberikan solusi bagi korporasi dan negara di dalam mencari remedy demi menjaga aktivitas publik/masyarakat dari pelanggaran HAM oleh korporasi/perusahaan.

g. Tata Kelola Organisasi (Organizatinal Gvernoance)

Sebagaimana halnya manusia yang tidak bisa hidup tanpa orang lain, demikian pula perusahaan tidak bisa hidup, beroperasi dan memperoleh keuntungan bisnis tanpa pihak lain. Ini menuntut agar perusahaan perlu dijalankan dengan tetap bersikap tanggap, peduli dan bertanggung jawab atas hak dan kepentingan banyak pihak lainnya. Setiap perusahaan harus bertanggung jawab atas tindakan dan kegiatan bisnisnya yang mempunyai pengaruh atas orang-orang tertentu, masyarakat, serta lingkungan di mana perusahaan itu beroperasi. ${ }^{21}$

\section{Perbedaan Regulasi CSR di Indonesia, ISO 26000, dan Beberapa Negara}

Setelah melihat adanya beberapa pengaturan CSR, baik di Indonesia, ISO 26000, dan beberapa negara lainnya, maka terdapat suatu kesimpulan terkait

20 Rony Irawan, Corporate Social Responsibility Tinjauan Menurut Peraturan Perpajakan Di Indonesia, Fakultas Ekonomi Unika Widya, Surabaya, 2008, hlm 43

${ }^{21}$ A. Sonny Keraf, Etika Bisnis Tuntutan dan Relevansinya, Kanisius, Yogyakarta, 2002, hlm 122 
beberapa perbedaan pengaturan dan prinsip yang diperoleh, yakni akan disimplifikasikan dalam tabel berikut ini.

\begin{tabular}{|c|c|c|}
\hline Unsur & ISO 26000 & Beberapa Negara \\
\hline Substansi & 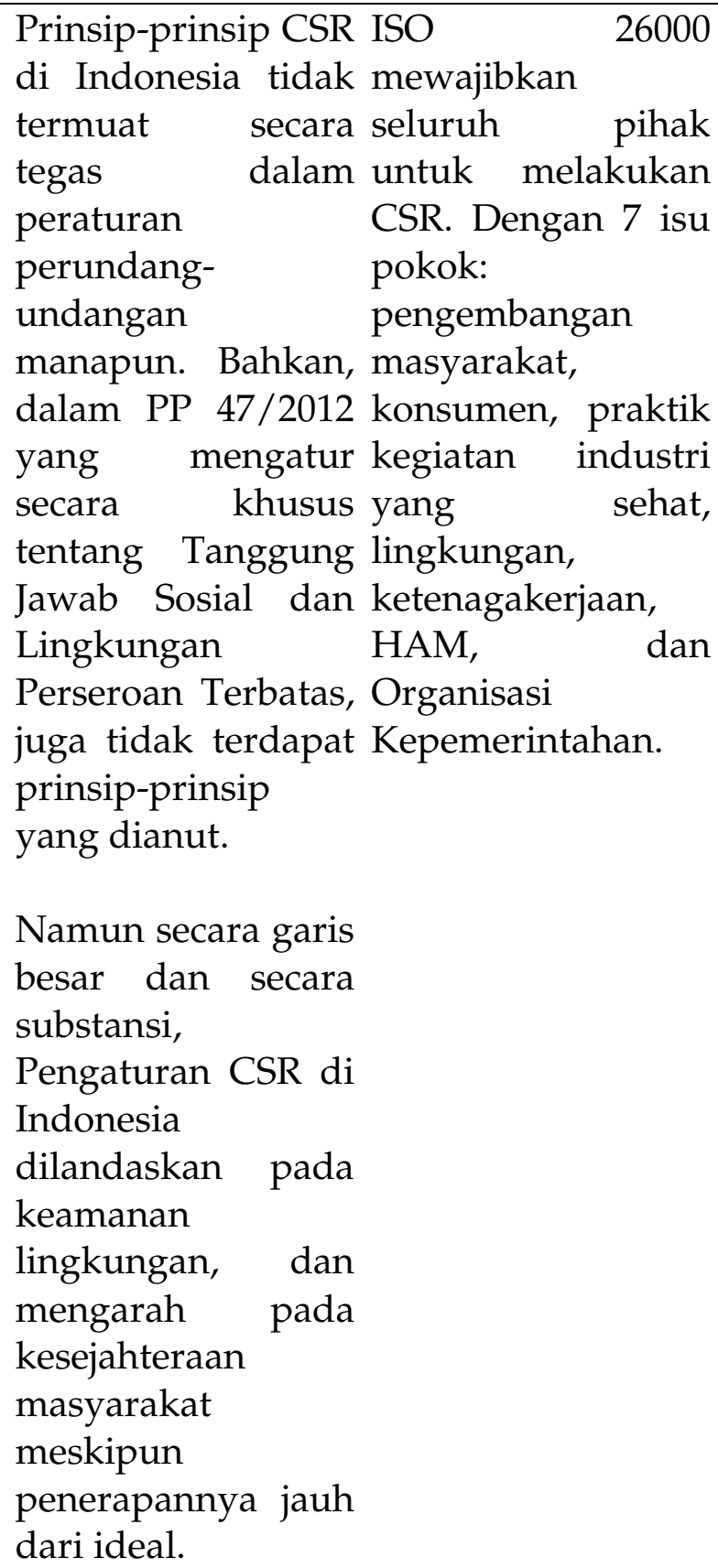 & $\begin{array}{l}\text { Prinsip-prinsip } \\
\text { pelaksanaan CSR } \\
\text { diberbagai negara } \\
\text { berbeda-beda. } \\
\text { Namun pada } \\
\text { intinya kebanyakan } \\
\text { negara menganut } \\
\text { prinsip ekonomi, } \\
\text { lingkungan, dan } \\
\text { sosial dalam } \\
\text { melaksanakan CSR. }\end{array}$ \\
\hline Aturan-Aturan & $\begin{array}{l}\text { UU PT, UU PM, UU ISO } 26000 \\
\text { Minyak Bumi, UU } \\
\text { PPLH, UU Panas } \\
\text { Bumi, UU Minerba, } \\
\text { dan UU Fakir } \\
\text { Miskin, PP No. } \\
47 / 2012 \text {, PP No. } \\
23 / 2010, \quad \text { Permen } \\
\text { BUMN 2013 }\end{array}$ & $\begin{array}{l}\text { Peraturan } \\
\text { perundang- } \\
\text { undangan yang } \\
\text { berlaku dalam } \\
\text { negara masing- } \\
\text { masing, dalam } \\
\text { berbagai bentuk. }\end{array}$ \\
\hline
\end{tabular}




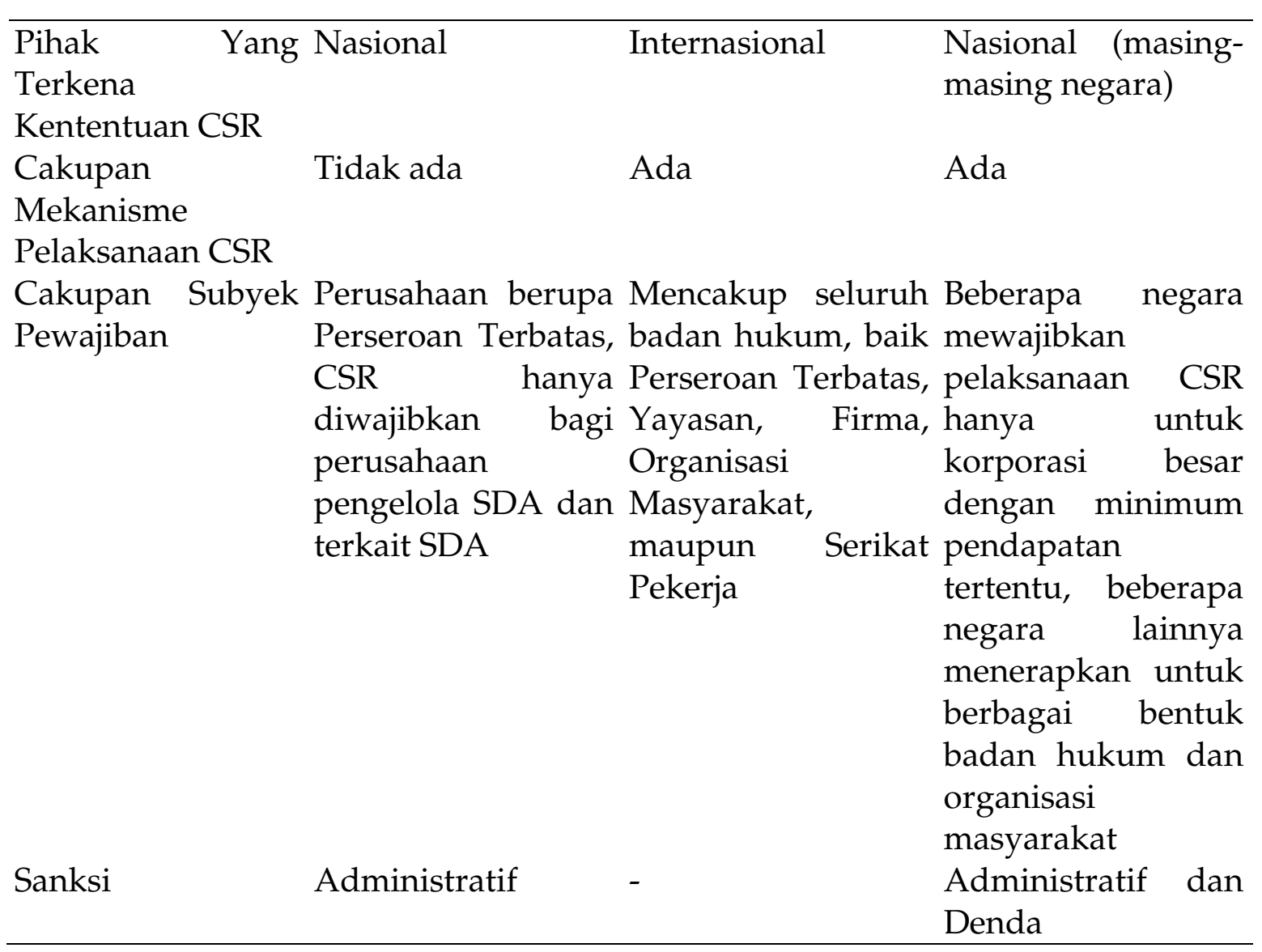

Regulasi CSR di Indonesia masih tersebar di beberapa peraturan perundangundangan. Dari seluruh aturan tersebut, pengaturan CSR masih secara sempit yakni diwajibkan hanya bagi perusahaan yang bergerak dan berkaitan dengan SDA. CSR hanya diwajibkan bagi perusahaan yang menyentuh aspek SDA dan hanya diwajibkan bagi badan hukum yang berbentuk Perseroan Terbatas. Sedangkan, perusahaan non SDA dan badan hukum selain Perseroan Terbatas tidak diwajibkan untuk melaksanakan CSR.

Pengaturan CSR di Indonesia belum sejalan dengan prinsip-prinsip yang terdapat dalam ISO 26000. Dalam ISO 26000, CSR tidak hanya diperuntukkan bagi korporasi semata, namun juga diperuntukkan bagi semua organisasi, baik swasta maupun publik. ISO 26000 menyediakan standar pedoman mengenai tanggung jawab sosial (menghapuskan kata "corporate" sehingga menjadi "social responsibility") secara sukarela mencakup semua sektor badan publik atau badan privat yang tidak berpedoman pada bergerak dalam bidang SDA atau non SDA. ISO 26000 juga mewajibkan pada seluruh badan hukum dan organisasi untuk melaksanakan CSR termasuk dalam hal ini Perseroan Terbatas, Firma, CV, Yayasan, Organisasi Masyarakat, maupun serikat buruh. Jika dilihat dari pembahasan yang telah dilakukan, di Indonesia, pelaksanaannya program- 
program CSR belum sesuai dengan hakikat pelaksanaan CSR sebagaimana yang tertuang dalam ISO 26000.

\section{Regulasi dan Formulasi Corporate Social Responsilibilty bagi Perusahaan (Non SDA) di Indonesia Berdasarkan ISO 26000}

Pembentukan pengaturan terkait CSR, khususnya yang terdapat dalam UU PT, tidak terlepas dari aksi dan tuntutan masyarakat dan Lembaga Swadaya Masyarakat (LSM).22 Begitu cepat dan derasnya dinamika sosial masyarakat, serta semakin menurunnya peran pemerintah dan semakin vitalnya peran sektor swasta dalam pembangunan. Kondisi ini dipicu dengan meningkatnya kesadaran dan tuntutan tentang keadilan sosial, lingkungan hidup dan hak-hak Asasi Manusia (HAM) serta law enforcement serta well informed dalam aktivitas usaha setiap perusahaan. Fakta menunjukkan bahwa kurangnya tanggung jawab dari perusahaan-perusahaan baik nasional maupun multinasional yang beroperasi di Indonesia dari luar dari tanggung jawabnya dalam mengelola lingkungan.

Banyak perusahaan non SDA yang hanya melakukan kegiatan operasional tetapi kurang sekali memberikan perhatian terhadap lingkungan, kepentingan sosial dan ekonomi masyarakat disekitarnya. Misalnya saja perusahaan non SDA yang telah melakukan pencemaran lingkungan. Di tahun 2018, Perusahaan Tekstil bernama Indobarat didenda sebesar Rp. 2.000.000.000,00 akibat telah mencemari sungai di Purwakarta. Kejaksaan Negeri Purwakarta telah mengeksekusi putusan Mahkamah Agung Nomor: 574 K/Pid.Sus LH/2017 tertanggal 18 Juli 2017 yang menghukum Perusahaan Indobarat melakukan pencemaran Sungai Kalimati di Purwakarta akibat kegiatan usahanya. ${ }^{23}$

Di Australia dan Cina, CSR telah menjadi sebuah penilian hukum oleh otoritas pasar modal yang dituangkan dalam bentuk public report, di samping penilaian publik sendiri. Ternyata perusahaan yang melaksanakan CSR dalam aktivitas usahanya berdampak positif terhadap sahamnya di bursa. Atas dasar argumentasi tersebut, memang CSR yang semula adalah tanggung jawab nonhukum (responsibility) diubah menjadi tanggung jawab hukum (liability). Untuk itu CSR harus dimaknai sebagai instrumen untuk mengurangi praktik bisnis yang tidak etis. ${ }^{24}$

22 Ely Suhayati, Penerapan Corporate Social Responsibility untuk Meningkatkan Citra Universitas, Majalah Ilmiah Unikon, Vol. 7, No. 2, diakses pada https://jurnal.unikom.ac.id/_s/data/jurnal/v07-n02/volume-72-artikel2.pdf/pdf/volume-72-artikel-2.pdf

23 Irwan Nugraha, Cemari Sungai, Pabrik Tekstil Indobarat Dibukum Denda Rp 2 Miliar, diakses pada https://regional.kompas.com/read/2018/01/23/11291801/cemari-sungai-pabrik-tekstil-indobarat-dihukumdenda-rp-2-miliar

${ }^{24}$ Rosita Candra Kirana, "Studi Perbandingan Pengaturan tentang Corporate Social Responsibility di beberapa Negara dalam Upaya Perwujudan Prinsip Good Corporate Governance”, Tesis, Universitas Sebelas Maret, (2019), hlm 166 
Apabila CSR ditetapkan di dalam anggaran perusahaan maka tentu saja dapat memberatkan perusahaan, apalagi perusahaan yang sedang tahap berkembang. Oleh karena itu, ada frase "kepatutan dan kewajaran" sebagai exit clause bagi pemerintah untuk menentukan pelaksanaan CSR. Maksudnya adalah sebagai alasan pemerintah untuk menerapkan CSR kepada perusahaan-perusahaan yang sedang berkembang, tentu saja penerapan CSR diutamakan kepada perusahaan-perusahaan yang bergerak dalam bidang SDA. Tetapi tidak tertutup kemungkinan untuk dilakukan oleh perusahaan non SDA seperti perusahaan Indobarat di Purwakarta sebagaimana telah dicontohkan sebelumnya.

Sebuah kemajuan apabila kekurangan-kekurangan dalam aturan CSR di Indonesia yang ada dapat diperbarui dengan pengadopsian terhadap panduan CSR dalam ISO 26000 ke dalam sistem hukum Indonesia, dengan catatan ada peningkatan atas adopsi tersebut yakni perubahan sifat dari sebatas panduan dalam ISO 26000 menjadi sebuah norma hukum yang memaksa dalam sebuah UU baru yang lebih kompleks dan luas. Berdasarkan konsep ISO 26000, penerapan CSR hendaknya terintegrasi di seluruh aktivitas organisasi yang mencakup 7 isu yang telah dijelaskan pada sub bab sebelumnya. Oleh karena itu membuat regulasi mengenai CSR yang lebih kompleks dan jelas sudah merupakan sebuah keharusan.

Diperlukan formulasi pasal-pasal baru yang mengadopsi prinsip-prinsip yang terdaoat dalam ISO 26000 untuk mengatur pelaksanaan CSR di Indonesia. Beberapa pasal yang terdapat dalam UU PT, UU PM, UU Minyak Bumi, UU PPLH, UU Panas Bumi, UU Minerba, dan UU Fakir Miskin, 2 Peraturan Pemerintah yakni PP No. 47/2012 dan PP No. 23/2010, maupun 1 Peraturan Menteri yakni Permen BUMN 2013, perlu diformulasikan dan dijahit menjadi satu dalam suatu Undang-Undang khusus yang mengatur tentang pelaksanaan CSR.

Undang-undang yang bersifat khusus ini, selain untuk menjahit aturan yang terpencar diberbagai peraturan perundang-undangan, juga berfungsi untuk memformulasikan pasal-pasal baru yang mengadopsi prinsip-prinsip dan nilai-nilai dari ISO 26000. Pewajiban CSR bagi perusahaan non SDA yang tidak hanya terbatas pada bentuk PT semata, namun juga badan hukum dan berbagai bentuk kegiatan usaha yang lain. Formulasi pewajiban ini harus didasarkan pada kemampuan perusahaan untuk melaksanakan CSR, dampak yang ditimbulkan pada lingkungan, dan lokasi keberadaan kegiatan usaha. Adapapun berkaitan dengan mekanisme pelaksanaan CSR, dapat pula diformulasikan melalui pembentukan lembaga resmi atau institusi negara yang melaksanakan dan memiliki kewenangan untuk melakukan penilaian dan pengontrolan atas pelaksanaan CSR. 
Regulasi khusus berupa UU baru untuk mengatur implementasi dan mekanisme pelaksanaan CSR di Indonesia yang terpadu dan terkodifikasi. Pengaturan CSR di Indonesia yang masih tersebar di beberapa peraturan perundang-undangan perlu diformulasikan ulang dengan mengadopsi prinsipprinsip pelaksanaan CSR yang terdapat dalam ISO 26000. CSR dalam hal ini juga dilaksanakan dalam rangka memberikan perlindungan masyarakat terhadap dampak yang ditimbulkan korporasi. Perlindungan tersebut yakni dengan melaksanakan tiga prinsip yang terkandung dalam The United Nation Guiding Principle on Bussiness and Human Rights (UNGP) yakni meliputi Protect (melindungi), Respect (menghormati), dan Remedy (pemulihan).

Formulasi ulang pengaturan CSR di Indonesia yang mengadopsi prinsipprinsip ISO 26000 bertujuan agar perusahaan yang ingin berkelanjutan harus memperhatikan 3P yakni selain mendulang 'profit', perusahaan harus terlibat pada pemenuhan kebutuhan masyarakat 'people' dan berkontribusi aktif untuk menjaga kelestarian lingkungan 'planet'. Perusahaan, apapun kegiatan usahanya, baik yang bergerak dalam usaha pengelolaan SDA maupun non SDA, diharapkan untuk tidak hanya mengedepankan aspek ekonomi semata (single bottom line), tetap juga harus mempertimbangkan dan mempertanggungjawabkan aspek sosial dan lingkungan (triple bottom line).

\section{Penutup}

Pengaturan CSR di Indonesia tidak sesuai dengan pengaturan yang terdapat dalam ISO 26000. Regulasi CSR di Indonesia masih tersebar di beberapa peraturan perundang-undangan yakni dalam 7 undang-undang yakni: UU PT, UU PM, UU Minyak Bumi, UU PPLH, UU Panas Bumi, UU Minerba, dan UU Fakir Miskin, 2 Peraturan Pemerintah yakni PP No. 47/2012 dan PP No. 23/2010, dan 1 Peraturan Menteri yakni Permen BUMN 2013. Dari seluruh aturan tersebut, pengaturan CSR di Indonesia masih secara sempit yakni diwajibkan hanya bagi perusahaan yang bergerak dan yang berkaitan dengan SDA, namun itu masih jauh dari cukup. Terlebih lagi pengaturan CSR di Indonesia tersebut tidak sejalan dengan pengaturan yang terdapat dalam ISO 26000.

Perlu adanya regulasi secara khusus yang mengatur mengenai implementasi dan mekanisme pelaksanaan CSR di Indonesia yang terpadu dan terkodifikasi, dengan mengadopsi prinsip-prinsip pelaksanaan CSR yang terdapat dalam ISO 26000. Pengaturan mengenai CSR perlu diformulasikan dalam bentuk UU baru yang di dalamnya memuat dua ketentuan utama yakni pelaksanaan CSR bagi perusahaan SDA dan pelaksanaan CSR bagi perusahaan Non-SDA. Pewajiban CSR untuk seluruh bentuk perusahaan akan memberikan keadilan dan kepastian hukum bagi 
seluruh pihak, dan juga akan memberikan kepastian hukum untuk terselenggaranya CSR yang patut dan wajar dengan parameter yang jelas dan terukur.

\section{Daftar Pustaka}

\section{Buku}

Keraf, A Sonny, Etika Bisnis Tuntutan dan Relevansinya, Kanisius, Yogyakarta, 2002. Elly Erawaty, AF., Persoalan Hukum Seputar Tanggung Jawab Sosial Perseroan Dalam Perundang-Undangan Ekonomi Indonesia, Kementerian Hukum \& HAM RI, Direktorat Jenderal Peraturan Perundangan-Undangan, Media Publikasi Peraturan Perundang-Undangan dan Informasi Hukum, Jakarta, 2010.

Ibrahim, Johnny, Teori dan Metodologi Penelitian Hukum Normatif, Bayu Media Publishing, Surabaya, 2005.

Bertens, K., Pengantar Etika Bisnis, Kanisius, Yogyakarta, 2000.

Fajar, Mukti, Tanggungjawab Sosial Perusahaan di Indonesia, Pustaka Pelajar, Yogyakarta, 2013.

Muhadjir, Noeng, Metode Penelitian Kualitatif, Cetakan I, Penerbit Rake Saarasin, Yogyakarta, 2000.

Irawan, Rony, Corporate Social Responsibility Tinjauan Menurut Peraturan Perpajakan Di Indonesia, Fakultas Ekonomi Unika Widya, Surabaya, 2008.

Rongiyati, Sulasi, Aspek Hukum Pengaturan Tanggung Jawab Sosial dan Lingkungan dalam Undang- Undang Perseroan Terbatas, Jakarta, DPR RI.

\section{Artikel Jurnal dan Makalah}

Asep Mulyadi, "Pengembangan Sumber Daya Manusia dalam Mendukung Program Konservasi Lingkungan Laguna Segaraanakan", dalam http:/ / ejournal.upi. edu/index.php/gea/article/viewFile/1682/1134, Akses 2 Maret 2019

Burhan Bungin, Metodologi Penelitian Kualitatif: Komunikasi, Ekonomi, dan Kebijakan Publik serta Ilmu-ilmu Sosial Lainnya, Prenada Media Group, Jakarta, 2010.

Edi Suharto, "Pengembangan Masyarakat Dalam Praktik Pekerja Sosial", Makalah disampaikan pada Pelatihan Pengorganisasian dan Pengembangan Masyarakat, Jurusan Ilmu Kesejahteraan Sosial FISIP Universitas Jember, Jember, 28 September 2006.

Ely Suhayati, "Penerapan Corporate Social Responsibility untuk Meningkatkan Citra Universitas", Majalah Ilmiah Unikon, Vol. 7, No. 2, diakses pada https://jurnal.unikom.ac.id/_s/data/jurnal/v07-n02/volume-72-artikel2.pdf/pdf/volume-72-artikel-2.pdf

\section{Tugas Akhir}

Rosita Candra Kirana, "Studi Perbandingan Pengaturan tentang Corporate Social Responsibility di beberapa Negara dalam Upaya Perwujudan Prinsip Good Corporate Governance", Tesis, Universitas Sebelas Maret. 


\section{Internet}

Sukarmi, "Tanggung jawab Sosial Perusahaan (Corporate Social Responsibility) dan Iklim Penanaman Modal", Akses 18 Januari 2019, diakses pada http/ / www.madani-ri.com

Dinara Falif, Kehadiran Pabrik di Tengah Permukiman, 22 Maret 2020, diakses pada 1 Juni 2020, pada https://www.kompasiana.com/ dinarafalif/5e76d6de097f367e6e39f572/kehadiran-pabrik-di-tengahpermukiman-warga

"Penyerapan Tenaga Kerja Industri Manufaktur Terus Meningkat". Akses 15 april 2020, diakses pada https:/ / kemenperin.go.id/artikel/20288/PenyerapanTenaga-Kerja-Industri-Manufaktur-Terus-Meningkat.

"Tiga perusahaan Multinasional Tambah Investasi di Indoensia". Akses 15 April 2020, diakses pada https://kompas.id/baca/ekonomi/2019/01/25/tigaperusahaan-multinasional-tambah-investasi-di-indonesia/.

"Sektor Industri Sumbang 30\% Penerimaan Pajak" Akses 15 april 2020, diakses pada https://m.medcom.id/ekonomi/mikro/GbmXIDLN-sektorindustri-sumbang-30-penerimaan-pajak.

"Menperin: Industri di RI Berkembang Pesat dalam 10 Tahun Terakhir (31 Mei 2019)", Akses 15 April 2020, diakses pada https://www.liputan6.com/ bisnis/read/3980293/menperin-industri-di-ri-berkembang-pesat-dalam10-tahun-terakhir,

"Beginilah Visualisasi Pencemara Industri di Hari Lingkungan Hidup"dalam Akses 15 April 2020, diakses pada https://www.mongabay.co.id/2016/ 06/06/beginilah-visualisasi-pencemaran-industri-di-hari-lingkunganhidup/.

Irwan Nugraha, Cemari Sungai, Pabrik Tekstil Indobarat Dihukum Denda Rp 2 Miliar, diakses pada https:/ / regional.kompas.com/read/2018/01/23/11291801/ cemari-sungai-pabrik-tekstil-indobarat-dihukum-denda-rp-2-miliar

Kementerian Perindustrian Republik Indonesia, "Indonesia Masuk Kategori Negara Industri", dalam https://kemenperin.go.id/artikel/18473/IndonesiaMasuk-Kategori-Negara-Industri. Akses 15 april 2020

Manufacturing value added (MVA) sebagaimanana didefinisikan oleh UNIDO (United Nations Industrial Development Organization) adalah "Manufacturing value added (MVA) of an economy is the total estimate of netoutput of all resident manufacturing activity units obtained by adding up outputs and subtracting intermediate inputs." Dalam https://stat.unido.org/content/ learning-center/what-is-manufacturing-value-added\%253f

Mas Achmad Daniri, "Standarisasi Tanggungjawab Sosial Perusahaan”, Akses 10 Oktober 2018, diakses pada http://kadin-indonesia.or.id/enm/images/ dokumen/KADIN-167-3770-15042009.pdf

\section{Putusan Pengadilan}

Putusan Mahkamah Agung Nomor: 574 K/Pid.Sus LH/2017, 18 Juli 2017

Putusan Mahkamah Konstitusi No. 53/PUU-VI/2008. 